\title{
PENDAMPINGAN PENGELOLAAN KEUANGAN BAGI BENDAHARA ASRAMA DI PONDOK PESANTREN NGALAH SENGONAGUNG PURWOSARI PASURUAN
}

\author{
M. Sholihun'1), Gatut Setiadi2) \\ 1)sholihunsmkdt1978@gmail.com, 1)gatutsetiadi@iaiskjmalang.ac.id \\ 1), 2)IAI Sunan Kalijogo Malang
}

\begin{abstract}
Abstrak: Manajemen keuangan menjadi hal yang sanagt penting dalam menjalankan berbagai sistem pendidikan di pondok pesantren. Salah satunya penerapan manajemen keuangan di Pondok Pesantren Ngalah Purwosari. Ada tiga faktor yang berperan dalam sistem penyelenggaraan Pondok Pesantren yaitu, manajemen sebagai faktor upaya, organisasi sebagai faktor Sarana, dan administrasi sebagai faktor karsa. Ketiga faktor ini memberi arah dan perpaduan dalam merumuskan, mengendalikan, penyelenggaraan, mengawasi serta menilai pelaksanaan kebijakan kebijakan dalam usaha menyelenggarakan kegiatan pendidikan yang sesuai dengan tujuan setiap Pondok Pesantren. Untuk menyesuaikan hal tersebut maka diperlukan adanya pendampingan pengelolaan keuangan bagi bendahara di setiap asrama pondok pesantren Ngalah dengan tujuan semua bendahara pondok dan asrama dapat mengimplementasikan pengelolaan keuangan dengan baik yakni dalam hal manajemen keuangan, organisasi pengelola, dan administrasi pengelolaan. Hasil dari pendampingan ini yakni: (1) bekal pemahaman secara menyeluruh bagi para bendahara selaku pengelolah keuangan; (2) pembuatan pedoman pembuatan anggaran keuangan di pondok pesantren Ngalah yang akan dijadikan acuan sehingga dalam pengelolaan akan muncul keseragaman dalam pengelolaan keuangan. 3) Kelengkapan informasi keuangan sangat terkait dengan data pendukung yang ada, terutama bukti transaksi seperti kwitansi, faktur, jurnal umum, buku besar dan beberapa pendukung laporan keuangan.
\end{abstract}

Kata Kunci: Pendampingan, Pengelolaan keuangan, Pondik pesantren Ngalah

\begin{abstract}
Financial management is very important in running various education systems in Islamic boarding schools. One of them is the implementation of financial management at the Ngalah Purwosari Islamic Boarding School. There are three factors that play a role in the implementation system of Islamic boarding schools, namely, management as a factor of effort, organization as a factor of means, and administration as a factor of initiative. These three factors provide direction and integration in formulating, controlling, administering, supervising and assessing the implementation of policy policies in an effort to organize educational activities in accordance with the objectives of each Islamic Boarding School. To adjust this, it is necessary to provide financial management assistance for the treasurer in each boarding
\end{abstract}


school boarding school Ngalah with the aim that all boarding school treasurers can implement financial management properly, namely in terms of financial management, management organization, and management administration. The results of this assistance are: (1) provision of a comprehensive understanding for treasurers as financial managers; (2) preparation of guidelines for the preparation of financial budgets at the Ngalah Islamic boarding school which will be used as a reference so that in management there will be uniformity in financial management. 3) Completeness of financial information is closely related to existing supporting data, especially evidence of transactions such as receipts, invoices, general journals, ledgers and several supporting financial reports.

Keywords: Assistance, Financial Management, Pondik Pesantren Ngalah

\section{PENDAHULUAN}

Manajemen keuangan menurut Sudrajat merupakan tindakan pengurusan/ ketatausahaan keuangan yang meliputi pencatatan, perencanaan, pelaksanaan, pertanggungjawaban dan pelaporan. ${ }^{1}$ Sedangkan Mulyasa memberikan pengertian bahwa manjemen keuangan sekolah merupakan bagian dari kegiatan pembiayaan pendidikan, yang secara keseluruhan menuntut kemampuan sekolah untuk merencanakan, melaksanakan dan mengevaluasi serta mempertanggungjawabkan secara efektif dan transparan. ${ }^{2}$ Dengan demikian, manajemen keuangan sekolah dapat diartikan sebagai rangkaian aktivitas mengatur keuangan sekolah mulai dari perencanaan, pembukuan, pembelanjaan, pengawasan dan pertanggungjawaban keuangan sekolah

Mengingat antara sekolah dan pondok pesantren memiliki kesamaan substansi dan kesamaan visi-misi dari setiap instansi, maka berdasarkan defenisi di atas penulis dapat menyimpulkan bahwa manajemen keuangan pondok pesantren merupakan kegiatan yang dilakukan guna mencapai tujuan pondok pesantren yang telah direncanakan dengan mengembangkan dan mengelola sumber daya dan sumber dana

${ }^{1}$ Akhmad Sudrajat, Konsep dasar manajemen keuangan sekolah, (Semarang: Pustaka Rizki Putra, 2013), hal.130.

${ }^{2}$ E. Mulyasa, Manajemen Berbasis Sekolah, (Bandung: Remaja Rosdakarya, 2006), hal. 194. 
serta potensi-potensi yang dimiliki dalam sistem pondok pesantren secara efektif dan efisien. Manajemen keuangan pondok pesantren merupakan salah satu substansi manajamen lembaga pendidikan yang akan turut menentukan kelancaran kegiatan pondok pesantren. Seperti halnya yang terjadi pada substansi manajemen pendidikan pada umumnya, kegiatan manajemen keuangan pondok pesantren seyogyanya dilakukan melalui proses perencanaan, pengorganisasian, pengarahan, pengkoordinasian, pengawasan atau pengendalian. Beberapa kegiatan manajemen keuangan berupa kegiatan memperoleh dan menetapkan sumber-sumber pendanaan, pemanfaatan dana, pelaporan, pemeriksaan dan pertanggung jawaban.

Pondok pesantren yang pada awalnya dianggap sebagai lembaga pendidikan alternatif, dewasa ini sudah mengalai kenaikan kasta menjadi lembaga pendidikan solutif dan substantif. Saat ini pondok pesantren dianggap satu-satunya lembaga pendidikan yang tetap eksis membentuk karakter dan kepribadian (personality character) generasi penerus bangsa ini.

Ada tiga faktor yang berperan dalam sistem penyelenggaraan Pondok Pesantren yaitu, manajemen sebagai faktor upaya, organisasi sebagai faktor Sarana, dan administrasi sebagai faktor karsa. Ketiga faktor ini memberi arah dan perpaduan dalam merumuskan, mengendalikan, penyelenggaraan, mengawasi serta menilai pelaksanaan kebijakan kebijakan dalam usaha menyelenggarakan kegiatan pendidikan yang sesuai dengan tujuan setiap Pondok Pesantren.

Pondok pesantren sebagai lembaga pendidikan Islam tertua di Indonesia, saat ini telah banyak mengalami pergeseran orientasi dari format salaf ke modern sehingga berdampak pada kemampuan para santri dalam menguasai ilmu keislaman dari sumbersumber klasik (thuras). Maka, untuk mengembalikan posisi ke peran semula, yaitu melahirkan kader-kader ulama tentunya dengan melakukan pembenahan baik pada sisi internal maupun eksternal lembaga secara tersistematis dan terorganisir agar out putnya kelak memiliki keunggulan totalitas yakni tidak hanya unggul dalam kajian kitabkitab klasik semata namun juga unggul dalam pengetahuan umum, manajemen, dan administrasi sebagai penyeimbang dari kemajuan zaman. 
Sebagaimana dipaparkan pada latar belakang di atas, maka permasalahan kegiatan ini akan medeskripsikan dan mengungkap tentang: penerapan tiga faktor pengelolaan keuangan di pondok pesantren ngalah sengonagung, yakni sistem pengelolaan; organisasi pengelola; dan administrasi pengelolaan. Maka itu kegiatan pengabdian kepada masyarakat ini bertujuan untuk medeskripsikan dan menganalisis tentang: penerapan tiga faktor pengelolaan keuangan di pondok pesantren ngalah sengonagung, yakni system pengelolaan; organisasi pengelola; dan administrasi pengelolaan yang mengacu pada pendapatan.

\section{METODE PELAKSANAAN KEGIATAN}

Metode pelaksanaan kegiatan ini dilakukan dengan pendekatan metode ceramah, partisipatif, pendekatan kelompok, metode diskusi/Forum Group Discussion (FGD) dan pendampingan. Metode ceramah memiliki guna memberikan pemahaman yang lebih komprehensif kepada pengelola keuangan asrama di Pondok Pesantren Ngalah, sebab pentingnya peningkatan kualitas bendahara asrama dapat berdampak positif pada pelaksanaan berbagai program kegiatan formal dan non formal di Pondok Pesantren Ngalah. Dalam pelaksanaan pendampingan ini digunakan beberapa metode pendekatan yaitu; 1) pendekatan partisipatif dengan tujuan agar pengelola keuangan asrama dapat berpartisipasi secara aktif terhadap semua kegiatan mulai dari awal sampai akhir. 2) pendekatan kelompok merupakan pendekatan yang digunakan untuk melaksanakan program lanjutan yaitu untuk melaksanakan pelatihan pembukuan dan administrasi pada tahap awal, pelatihan manajemen keuangan koperasi, dan pelatihan pengembangan produk. Dan 3) prendekatan Edukatif, yaitu pendekatan yang dalam program maupun pelaksanaan pengabdian mengandung unsur pendidikan yang dapat mendinamisasikan pengelola keuangan asrama menuju kemajuan yang dicita-citakan.

\section{PEMBAHASAN DAN HASIL KEGIATAN}

\section{Gambaran Umum Lokasi Pondok Pesantren Dampingan}

Pendampingan ini di fokuskan pada implementasi tiga faktor di pengurus asrama 
dan pengurus pondok pesantren Ngalah yang berdomisili di Desa Sengonagung Kecamatan Purwosari Kabupaten Pasuruan yakni manajemen pengelolaan; organisasi pengelola; dan administrasi pengelolaan, dan ditinjau dari keadaan lokasi pondok pesantren Ngalah, lembaga ini berada dalam naungan Yayasan Darut Taqwa Sengonagung yang mengelolah pendidikan formal dan non formal. Pendidikan Formal yang ada yaitu MI, MTs, SMP, MA, SMA, SMK, dan Univertas Yudharta Pasuruan. Pondok pesantren Ngalah merupakan salah satu pendidikan non formal yang di asuh oleh $\mathrm{KH}$. Sholeh Bahruddin, beliau merupakan pendiri dan pengasuh pondok pesantren serta Pembina Yayasan Darut Taqwa sampai saat ini yang membawai beberapa asrama yang diasuh oleh putra/putri beliau dengan jumlah santri \pm 5000 (lima ribu), sehingga keuangan yang dikelolah sudah harus menggambarkan pengelolaan keuangan yang mudah difahami oleh semua pihak, apalagi beberapa pemangku kebijakan menginnginkan adanya laporan keuangan yang mudah difahami baik secara strandat akuntansi maupun laporan kas.

\section{Kondisi Pondok Pesantren Dampingan}

Berdasarkan hasil observasi di lapangan dan ditinjau dari keadaan lokasi pondok pesantren Ngalah, lembaga ini berada dalam satu naungan Yayasan Darut Taqwa Sengonagung yang mengelolah pendidikan formal dan non formal. Pendidikan Formal yang ada yaitu MI, MTs, SMP, MA, SMA, SMK, dan Univertas Yudharta Pasuruan. Pondok Pesantren Ngalah diasuh oleh K.H. Moh. Sholeh Bahruddin yang moderat dalam mengembangkan lembaga pendidikan yang bernuansa Islam dan dikemas dalam bentuk formal modern, sehingga Pondok Pesantren Ngalah yang berada di bawah Yayasan Darut Taqwa Sengonagung mempunyai potensi yang baik untuk masa akan datang atau menjadi barometer pengelolaan pendidikan di kabupaten Pasuruan. Sekolah swasta terbesar di kabupaten pasuruan adalah Darut Taqwa, baik tingkat SLTP ataupun tingkatan SLTA, bahkan untuk tingkatan perguruan tinggi, Universitas Yudharta Pasuruan merupakan perguruan tinggi terbesar di kabupaten pasuruan, oleh karena itu pengelolaan keuangan yang baik khususnya di pondok pesantren yang merupakan ruh yayasan darut taqwa merupakan hal yang sangat diperlukan demi keberlangsungan 
hidup suatu organisasi.

\section{Kondisi Yang Diharapkan}

Setelah adanya kegiatan pendampingan ini, seluruh pengurus pondok pesantren Ngalah Sengonagung dapat mengimplementasikan pengelolaan keuangan dengan baik terutama bendahara pondok dan asrama, yakni dalam hal manajemen keuangan, organisasi pengelola, dan administrasi pengelolaan.

\section{Strategi Pelaksanaan}

Strategi pendampingan pengelolaan keuangan dilakukan dengan pemberian materi pengelolaan keuangan yang baik, implementasi, dan evaluasi hasil yang diharapkan. Peran Pengurus asrama dan pengurus pondok sangat penting dalam menjalankan kertertiban pengelolaan keuangan terutama kepala asarama dan kepala pondok pesantren yang merupakan penggerak organisasi sangat strategis dalam menggerakkan, mengarahkan dan membimbing bendahara sebagai pelaku, dan pengelolah keuangan yang diharapkan sesuai dengan ketentuan dan kebijakan umum pondok pesantren. Selain itu pengasuh asrama dan pengasuh pondok yang memegang kewenangan penuh dalam mengontrol dan mengendalikan opersaional kelembagaan sehingga sesuai dengan visi, misi dan tujuan pondok pesantren Ngalah Sengonagung Purwosari Pasuruan.

Dalam pengeloaan keuangan harus mengarah pada tigak faktor yakni (1) mampu memahami dan menerapkan sistem pengelolaan keuangan dengan baik terutama membuat anggaran jangka pendek, yakni dalam satu tahun, sehingga akan memberikan kontribusi yang signifikan terkait pengembangan program pondok pesantren, (2) mampu mengelola dengan baik terutama dalam penggunaan dana harus efektif dan efisien, (3) mampu menjaga dan menertibkan bukti transaksi keuangan serta dokumen keuangan agar informasi yang disajikan dalam menyampaikan laporan keuangan menjadi informasi yang lengkap dan akurat. Menurut Bastian (2010) akuntabilitas dapat dimaknai sebagai kewajiban untuk menyampaikan pertanggungjawaban atau untuk menjawab, menerangkan kinerja, dan tindakan seseorang badan hukum pimpinan kolektif atau organisasi kepada pihak yang memiliki hak atau berkewenangan untuk 
meminta keterangan atau pertanggungjawaban.

\section{A. Gambaran Kegiatan}

\section{Sistem Pengelolaan Keuangan}

Dalam penguatan sistem pengelolaan keuangan adalah dengan tahapan memberikan pemahaman terhadap pengelolaan keuangan yang baik yang mampu memrikan informasi seutuhnya terkait dengan proses pengelolaan mulai dengan menjelaskan sistem keuangan sentral yang setiap item pendapatan merupakan pendapatan yayasan, dengan memberikan pemahaman bahwa kebutuhan lembaga merupakan kebutuhan yayasan yang dialokasikan kepada lembaga dengan mempertimbangkan pendapatan dan kebutuhan lembaga masing-masing. Dalam hal pembagian pendapatan lembaga harus mempertimbangkan pengembangan secara umum yang dilakukan yayasan, sehingga kebutuhan lembaga harus memperhatikan pada skala prioritas dengan tetap mempertimbangkan kebutuhan lembaga lain jalan keluar untuk subsidi silang. Subsidi silang dimaksudkan adalah melihat lembaga yang kategori masih belum produktif dalam memenuhi kebutuhan lembaganya.

Pengelolaan keuangan di pondok pesantren Ngalah Sengonagung merupakan hal yang tidak terpisah dengan Yayasan Darut Taqwa Sengonagung. Dalam pengelolaannya keuangan pondok pesantren menjadi satu pendapatan dengan madrasah diniyah darut taqwa dan madrasatul qur'an, hal ini memberikan asumsi yang membingunkan ketika tidak dijelaskan pembagian kuota anggaran masing-masing lembaga yang masingmasing membutuhkan anggaran untuk operasional dan gaji pengelolanya.

Penerapan pengelolaan keuangan dengan sistem pendapatan yang menyatu dengan lembaga lain, harus diperjelas dengan pedoman penggunaan anggaran agar masingmasing lembaga mampu dan lebih efisien dalam menggunakan anggarannya dalam setiap periode. Kepala pondok pesantren sebagai leader yang mengendalikan seluruh aktifitas kegiatan dan pengelolaan keuangan harus mampu memberikan proporsi anggaran yang proporsional agar mampu memberikan keseimbangan dan kertersedian dana dalam menjalakan kegiatan masing-masing sehingga mampu mewujudkan capaian 
visi misi dan tujuannya masing-masing.

Penguatan sistem pengelolaan keuangan di Pondok Pesantren Ngalah dengan tahapan yang pertama adalah dengan membuat pedoman pengelolaan anggaran keuangan yang akan dibuat sebagai pedoman bagi semua bendahara yang mengelolah keuangan masing-masing asrama di pondok pesantren Ngalah, sehingga pendampingan awal setelah memberikan materi tentang pentingnya pengelolaan keuangan yang baik, dilanjutkan materi tentang membuat pedoman pembuatan angaran yang baik, ini dilakukan oleh seluruh bendahara asrama yang di koordinir oleh bendahara pondok pesantren. Dalam hal ini juga melibatkan seluruh bendahara asrama yang ditunjuk oleh pengurus pondok pesantren dalam rangka mempermudah pemahaman dan langkah teknis yang akan dipakai oleh semua bendahara asrama.

Penguatan pembuatan anggaran adalah sesuatu sistem pengelolaan yang harus dipahami, karena merupakan langkah awal dalam merencakan pengelolaan keungan yang akan dipakai acuan dalam merealisasikan keuangan dalam satu periode. Oleh karena itu seluruh bendahara asrama dalam hal ini selaku pengelola ditingkatan asrama harus mampu merencanakan dengan baik seleruh kebutuhan yang tempat kerjanya masing-masing.

\section{Organisasi Pengelola}

Didalam organisasi terdapat struktur yang memberikan tugas dan wewenang pada masing-masing bagian, hal ini memberikan batasan dalam melaksanakan tugas dan wewenangnya, agar masing-masing bagian berfungsi dan melaksanakan tugas sebagaimana mestinya. Kejelasan struktur akan memberikan kejelasan tugas yang dibebankan pada masing-masing bagian, sehingga antara bagian satu dengan bagian lain tidak saling berebut tugas, karena dari struktur yang jelas akan menggambarkan pembagian tugasnya. 

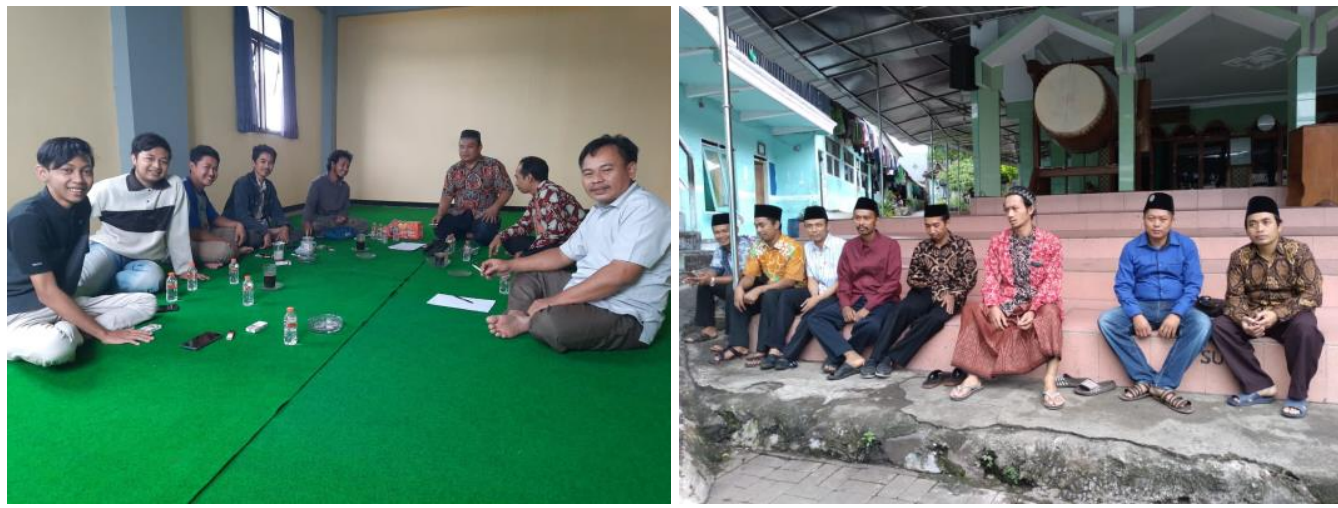

Gambar 1. Pengelola administrasi asrama Pondok Pesantren Ngalah

Organisasi pengelolah dalam pengelolaan keuangan lebih mengarah pada personal yang diberi tanggung jawab mengelolah keuangan, dalam hal ini adalah bendahara. Bendahara menjadi salah bagian dari struktur memiliki fungsi yang sangat penting, karena harus mampu menganalisa segala jenis kebutuhan organisasi baik yang merupakan skala prioritas ataupun pada skala tidak prioritas, hal menggambarkan bahwa personal yang diberi tanggung jawab sebagai bendahara merupakan personal yang harus memiliki keahlian dibidang pengelolaan keuangan disamping juga harus memiliki tingkat ketelitian secara admanistrasi, sehingga mampu mengelolah dengan baik. Menurut Sina, pengalaman keuangan adalah kemampuan untuk membuat pertimbangan atau pengambilan keputusan investasi untuk menentukan perencanaan dan pengelolaan investasi untuk mengetahui kegunaan manajemen keuangan untuk saat ini dan di masa mendatang. ${ }^{3}$

Penerapan pengelolaan keuangan dalam hal organisasi pengelolah adalah bendahara, yaitu bendahara pondok pesantren dan seluruh bendahara asrama di pondok pesantren Ngalah sengonagung, dan juga yang tidak kalah pentingnya adalah pemakai anggaran keuangan yang juga harus diberikan pemahaman untuk membelanjakan dengan benar dan melaporkan dengan benar kepada bendahara, sehingga akan mempermudah dalam memberikan informasi dalam menyampaikan

${ }^{3}$ Sina, P. G. 2012. Korelasi Pendidikan Karakter Terhadap Manajemen Keuangan Pribadi. Independent paper 2012 
laporan kepada kepala lembaga yang diteruskan kepada bendahara yayasan. Menurut Hilgret \& Jeanne 2003, kurangnya pengetahuan tentang prinsip-prinsip manajemen keuangan dan masalah-masalah keuangan akan menjadikan masalah pada saat praktek pengelolaan keuangan. ${ }^{4}$ Dan dibawah ini adalah alur pengelolaan keuangan bagi pengelolah keuangan.

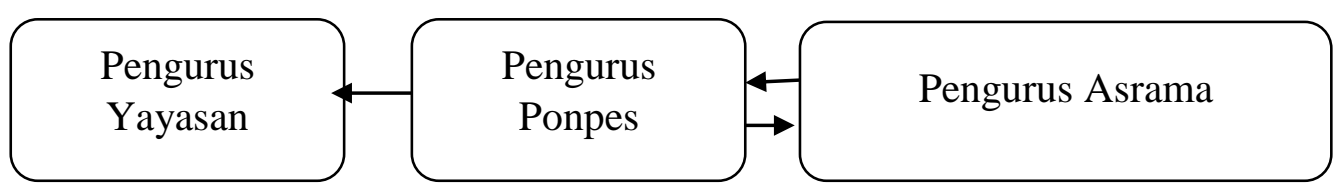

\section{Adaministrasi Pengelolaan}

Administrasi merupakan upaya pengelolaan data sebagai bukti dan dokumentasi kegiatan dalam pengelolaan keuangan, hal ini harus dilakukan oleh setiap pengelolah keuangan sebagai bentuk informasi yang akurat dalam memberikan penyajian laporan keuangan. Data dapat berubah menjadi informasi kalau diubah kedalam konteks yang memberikan makna. Oleh karena itu penyiapan bukti dan dokumen transaksi keuangan menjadi satu keharusan bagi setiap pengelolah keuangan.

Tertib administrasi dalam penerapan pengelolaan keuangan di Pondok Pesantren Ngalah menjadi hal harus ditingkatkan, karena masih ada pemahaman bahwa ketika transaksi sudah jelas dan rasional maka tidak dibutuhkan lagi bukti transaksi atau biasa yang dilakukan oleh pemakai dan pengelolah keuangan adalah sudah saling percaya. Hal ini harus ditertibkan lagi dalam upaya penyampaian informasi keuangan yang berbasis data. Penguatan dan kedisiplinan dalam menyiapkan bukti transaksi dan seluruh dokumen pengelolaan keuangan. Penataan bukti dan dokumen pengelolaan keuangan sebagai bentuk akuntabilitas keuangan. Akuntabilitas dapat dimaknai sebagai kewajiban untuk menyampaikan pertanggungjawaban atau untuk menjawab, menerangkan kinerja, dan tindakan seseorang badan hukum pimpinan kolektif atau organisasi kepada pihak yang memiliki hak atau berkewenangan untuk meminta keterangan atau pertanggungjawaban. Oleh karena itu penyajian informasi laporan keuangan yang

\footnotetext{
${ }^{4}$ Hilgret, MA, \& Jeanne, HM 2003, "Household Financial Management: The Connection between Knowledge and Behavior", Federal Reserve Bulletin. 2003.
} 
berbasis data merupakan hal yang harus dilakukan oleh setiap pengelolah keuangan.

Dalam perekaman segala bentuk transaksi keuangan hal harus dilakukan dan bukti serta dokumen yang harus ada adalah: (1) bukti transaksi berupa kwitansi atau faktur pembelian yang ditanda tangani oleh pemakai anggaran, kasir/bendahara selaku pengelolah keuangan, dan ketua/kepala lembaga selaku pemegang kewenangan anggaran, (2) Laporan kas atau jurnal umum yang menggambarkan seluruh transaksi dalam setiap periode, dan (3) Rekapitulasi penggunaan anggaran menurut kode item yang sudah dibakukan di yayasan Darut Taqwa Sengonagung Purwosari Pasuruan sebagai tahapan untuk mempermudah penyajian dan akuntabilitas laporan keuangan. Adanya tuntutan yang semakin besar terhadap pelaksanaan akuntabilitas publik menimbulkan implikasi bagi manajemen sektor publik untuk memberikan informasi kepada publik, salah satunya adalah informasi akuntansi berupa laporan keuangan.

Pelaksanaan pendampingan dirancang sesuai bagan berikut:

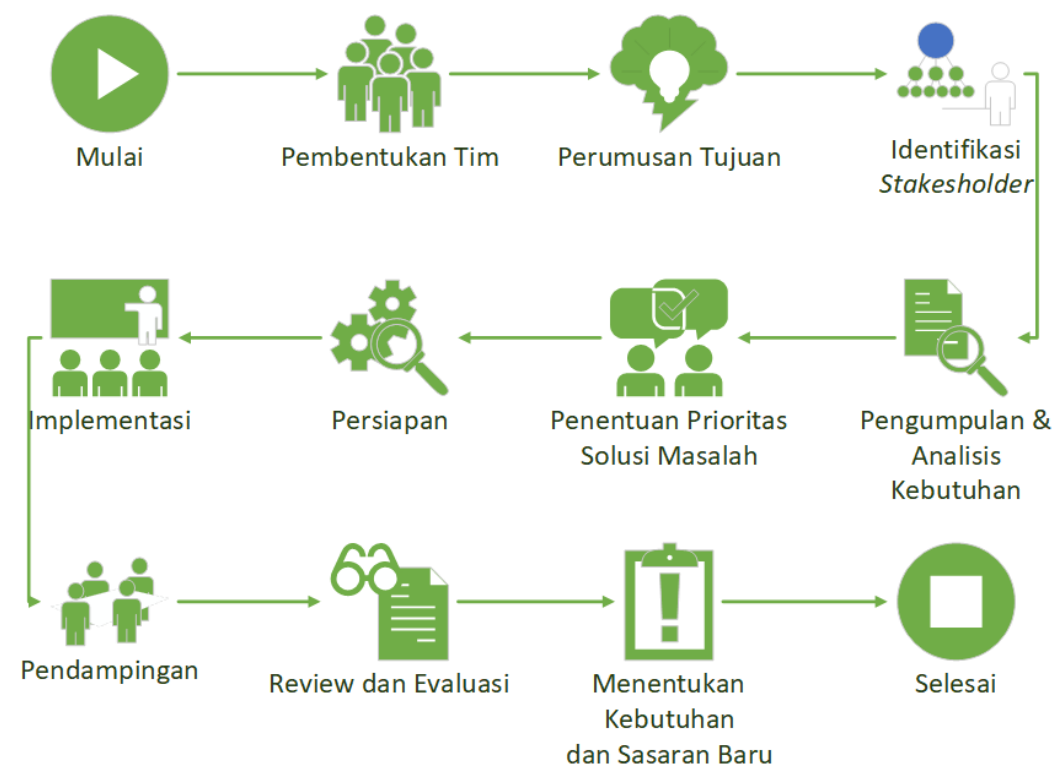

Gambar 2. Bagan Pelaksanaan Pendampingan Bendahara Asrama

\section{B. Hasil dari Pendampingan}

\section{Sistem Pengelolaan Keuangan}

Penerapan sistem pengelolaan keuangan pada pendampingan penguatan 
pengelolaan keuangan di Yayasan Darut Taqwa Sengonagung Purwosari Pasuruan adalah dengan memberikan pemahaman dan pemberian batasan dengan bentuk: (1) bekal pemahaman secara menyeluruh bagi para bendahara selaku pengelolah keuangan; (2) pembuatan pedoman pembuatan anggaran keuangan di pondok pesantren Ngalah yang akan dijadikan acuan sehingga dalam pengelolaan akan muncul keseragaman dalam pengelolaan keuangan. Dari pedoman yang ada dapat dijadikan acuan kebijakan dalam perencanaan anggaran, pelaksanaan, pengawasan, pelaporan, dan evaluasi, sehingga pengambilan keputusan terkait dengan pengelolaan keuangan bisa dipahami dan dilaksanakan oleh setiap pemakai dan pengelolah anggaran keuangan. Menurut Hilgret \& Jeanne 2003, keputusan keuangan yang baik dan benar dibutuhkan untuk meningkatkan pendapatan, mengelola pengeluaran, pembayaran pajak agar manajemen keuangan menjadi baik. ${ }^{5}$

\section{Organisasi Pengelola}

Setiap organisasi harus menyesuaikan sistem dengan kebutuhan pemakai sehingga tujuan penggunaan sistem informasi yang spesifik dapat berbeda-beda dari satu perusahaan dengan perusahaan lain. Penguatan organisasi pengelolah dengan cara memberikan kejelasan alur kewenangan dan penyempaian pelaporan, dari level lembaga sebagai pengguna anggaran dilanjutkan kepada pengurus pondok selaku pengelolah dan pengendali keuangan yang kemudian dilanjutkan kepada pengurus yayasan selaku pemegang penuh kewenangan dalam mengontrol dan mengendalikan pengelolaan keuangan di pondok pesantren. Sehingga pemegang kewenangan mampu memberikan dan menyajikan kepada struktur di atasnya. Laporan keuangan digunakan untuk memberikan jaminan kepada pengguna laporan keuangan dan pihak otoritas penguasa bahwa pengelolaan sumber daya telah dilakukan sesuai dengan ketentuan hukum dan peraturan lain yang telah ditetapkan.

\section{Administrasi Pengelolaan}

Pembuatan bukti transaksi merupakan suatu keharusan dalam suatu pengelolaan

${ }^{5}$ Hilgret, MA, \& Jeanne, HM 2003, "Household Financial Management: The Connection between Knowledge and Behavior", Federal Reserve Bulletin. 2003. 
keuangan, karena informasi yang akan disajikan sebagai laporan dan informasi keuangan memerlukan data akurat untuk menjaga akuntabilitas informasi yang disajikan. Informasi laporan keuangan yang akuntabel akan tercapai bilamana informasi yang disampaikan akurat, tepat waktu dan lengkap, sebagaimana yang sampaikan Hall bahwa informasi yang dihasilkan oleh sistem informasi dapat digunakan dalam pengambilan keputusan apabila informasi tersebut berkualitas artinya informasi tersebut harus memenuhi empat hal yaitu: relevan (relevance), akurasi (accuracy), tepat waktu (timeliness), lengkap (complete). ${ }^{6}$

Kelengkapan informasi keuangan sangat terkait dengan data pendukung yang ada, terutama bukti transaksi seperti kwitansi, faktur, jurnal umum, buku besar dan beberapa pendukung laporan keuangan, di Pondok Pesantren Ngalah Penerapan kedisiplinan dan penertiban data dan dokumen pendukung merupakan suatu harus ditertibkan, sehingga hasil dari pendampingan adalah dengan membuat bukti transaksi standart dan membuat standart pelaporan dengan menyertakan bukti-bukti yang ada, agar penertiban yang diinginkan dapat tercapai secara maksimal.

\section{Petunjuk penyusunan Rencana anggaran pendapatan dan belanja pesantren} (RAPBP)

1. RAPBP dibuat oleh asrama sebelum memasuki Tahun Anggaran Baru melalui sebuah Tim yang dibentuk oleh Pondok Pesantren Ngalah.

2. RAPBP yang telah disusun asrama diajukan kepada Pengurus Pondok pada bulan Sya'ban untuk selanjutnya dijadikan satu dengan RAPBP Pondok Pesantren.

3. RAPBP yang telah dijadikan satu dan selanjutnya menjadi RAPB Pondok Pesantren, kemudian diajukan ke Yayasan untuk mendapat pengesahan.

4. Pengesahaan RAPBP oleh Yayasan menjadi APBP akan dilakukan pada awal bulan syawal Tahun Pelajaran Baru untuk selanjutnya diserahkan kepada Pondok Pesantren untuk dilasanakan.

5. Pelaksanaan APBP oleh Pesantren tidak boleh menyimpang dari APBP yang telah disahkan oleh Yayasan.

${ }^{6}$ Hall, J.A., Sistem Informasi Akuntansi, Edisi 3, (Jakarta: Salemba Empat, 2001), hal. 56. 
6. Penyimpangan pelaksaan APBP biasanya terjadi bila Pesantren memasukkan program baru, yang tidak ada dalam APBP. Oleh karena itu jika muncul gagasan baru diluar APBP yang bersifat tidak mendesak, maka Pesantren hanya mengiventarisir gagasan tersebut untuk dituangkan dalam penyusunan RAPBP yang akan datang.

7. Perubahan APBP dapat dilakukan atas persetujuan Yayasan karena alasan yang dapat dipertanggungjawabkan.

8. Asrama yang belum mengajukan RAPB Tahun Pelajaran Baru pada waktu yang ditentukan, maka untuk bulan pertama tahun ajaran baru digunakan APBP Tahun Ajaran yang lalu disesuaikan dengan kondisi asrama yang bersangkutan.

9. Mata anggaran belanja:
a. Angaran belanja guru/pegawai.(HR, Insentif, Tunjangan, Kesejahteraan)
b. Anggaran belanja barang (Administrasi, Sarana, ATK dll.)
c. Anggaran belanja pemeliharaan(gedung atau sarana)
d. Anggaran belanja pembangunan.

10. Sumber pendapatan.

a. Syahriah Pondok Pesantren ( SPP)

Dibuat daya serap SPP tiap bulan /tahun dengan memperhatikan :

- Jumlah wajib bayar

- Jumlah wajib bayar yang mendapat keringanan $50 \%$

- Jumlah wajib bayar yang mendapat keringanan $100 \%$

- Ada bendahara SPP yang diangkat oleh yayasan atas usulan Kepala Pondok.

- Ada buku kas Umum

- Ada buku kas pembantu SPP dan Dana Infaq

- Ada laporan SPP yang dikirim ke Yayasan paling lambat tanggal 3 setiap bulan berikutnya.

b. Dana Infaq

- Dana Infaq direncanakan Yayasan dengan pertimbangan prioritas.

- Alokasi dana infaq 100\% dikelola Yayasan. 
11. Alokasi penggunaan SPP.
a. Pondok Pesantren $10 \%$
b. Yayasan $10 \%$
c. Asrama dan MQ 40\%
d. Madrasah Diniyah 40\%

12. Penyusunan RAPBP harus bertumpu pada kondisi obyektif Pesantren dan prioritas tujuan yang hendak dicapai. Dengan demikian besar anggaran belanja Pesantren maksimal hanya $90 \%$ dari hasil penerimaan.

\section{PENUTUP}

\section{Kesimpulan}

Pendampingan pembuatan pedoman dan penguatan pengelolaan keuangan di Pondok Pesantren Ngalah Sengonagung dengan tiga tahapan, pertama dengan memberikan pemahaman dan materi-materi yang memperjelas sistem pengelolaan keuangan dan kemudian dilanjutkan dengan membuat pedoman pembuatan anggaran keuangan yang akan menjadi acuan seluruh pengelola keuangan dalam menjalankan tugasnya serta memberikan kejelasan langkah-langkah konsultasi dan pertanggungjawaban terkait pengelolaan keuangan. Kedua, pendampingan bagi pengelolah keuangan adalah dengan memberikan alur tugas dan wewenang sebagai pengelola keuangan sehingga para pengelola keuangan akan bekerja dan berkonsultasi dengan benar sebagai alur tugas dan wewenang yang dibuat oleh pengurus pondok pesantren ngalah Sengonagung, penerapan dan pengawalan alur tugas dan wewenang sepenuhnya menjadi tugas pengurus pondok pesantren Ngalah Sengonagung.

Ketiga, penertiban bukti dan dokuman pengelolaan keuangan sebagai informasi yang lengkap juga menjadi item penting dalam pendampingan ini, karena pertimbangan sebelumnya adalah masih sangat minim tentang penertiban bukti transaksi dan beberapa dokumen pendukung laporan keuangan, sehingga pada tahapan ketiga pembuatan bukti transaksi dan pengawalan penertiban bukti dan dokumen pengelolaan keuangan menjadi satu keharusan untuk ditertibkan oleh pengurus pondok pesantren 
Ngalah Sengonagung.

\section{Saran}

1. Perlu adanya pemahaman bersama, motivasi yang tinggi, dan pengawalan dari pengurus Pondok Pesantren Ngalah Sengongaung dalam penerapan sistem pengelolaan keuangan di seluruh asrama di pondok pesantren Ngalah Sengonagung.

2. Perlu adanya pengawas penggunaan dan pengelolaan keuangan asrama di pondok pesantren Ngalah Sengonagung, agar organisasi pengelola di asrama berjalan sesuai dengan alur tugas dan wewenangnya.

3. Perlu adanya evaluasi rutin terkait dengan kediplinan dalam penerapan penertiban bukti transaksi dan dokumen pengelolaan keuangan agar penyajian informasi laporan keuangan sesuai dengan standar 


\section{DAFTAR PUSTAKA}

Hilgret, MA, \& Jeanne, HM 2003, 'Household Financial Management: The Connection between Knowledge and Behavior', Federal Reserve Bulletin.

Akhmad Sudrajat, Konsep dasar manajemen keuangan sekolah, (Semarang: Pustaka Rizki Putra, 2013), 36.

E. Mulyasa, Manajemen Berbasis Sekolah, (Bandung: Remaja Rosdakarya, 2006)

Kadarman Jusuf, Pengantar Ilmu Manajemen, ( Jakarta: PT Gramedia Pustaka Utama)

Hall, J.A., 2001, Sistem Informasi Akuntansi, Edisi 3, Salemba Empat. Jakarta.

Krishna, A, Rofaida, R. \& Sari, M. 2010. Analisis tingkat literasi keuangan di kalangan mahasiswa dan faktor-faktor yang mempengaruhinya (Survey pada Mahasiswa Universitas Pendidikan Indonesia). Proceedings of The $4^{\text {th }}$ International Conference on Teacher Education; Join Conference UPI \& UPSI Bandung, Indonesia, 8-10 November 2010

Sina, P. G. 2012. Korelasi Pendidikan Karakter Terhadap Manajemen Keuangan Pribadi. Independent paper 2012 